\title{
COMPARATIVE ANATOMICAL STUDY BETWEEN THE RIGHT AND LEFT SIDES OF THE AXILLARY NERVE IN RELATION TO DELTOPECTORAL APPROACH AND ACROMION
}

Antonio Carlos Tenor Junior', Fabiano Rebouças Ribeiro', Rômulo Brasil Filho', Cantídio Salvador Filardi Filho², Hilton Vargas Lutfi ${ }^{3}$, Eduardo Angoti Magri ${ }^{1}$

\section{ABSTRACT}

Objective: To establish anatomical parameters for the axillary nerve by measuring the distances to the acromion and the deltopectoral access, and to ascertain whether there are any differences in comparative measurements between the left and right sides. Method: An anatomical study on the path of the axillary nerve was conducted by dissecting 30 shoulders of 20 fresh adult cadavers. For comparative study, bilateral dissection was performed on 10 cadavers. Digital caliper gauges, accurate to the nearest $0.05 \mathrm{~cm}$, were used to measure the distances between the lateral extremity of the acromion and the anterior and posterior branches of the axillary nerve, and between the deltopectoral space and the anterior branch of the axillary nerve. Results: The shortest distance between the acromion and the axillary nerve was $5.47 \mathrm{~cm}$, and the greatest distance was
$7.06 \mathrm{~cm}$. The shortest distance between the deltopectoral groove and the axillary nerve was $3.94 \mathrm{~cm}$. A statistically significant difference was found using Wilcoxon's test in comparative measurements between the left and right sides for the distances between the posterior branch of the axillary nerve and the midpoint of the lateral border of the acromion (A-E), and between the anterior branch of the axillary nerve and the anterior extremity of the acromion (B-C), both of which were larger on the right side. Conclusions: The axillary nerve was situated between 5.47 and $7.06 \mathrm{~cm}$ distally to the acromion, and $3.94 \mathrm{~cm}$ laterally to the deltopectoral space. There was a statistically significant difference in the comparison between the left and right sides, and both measurements were larger on the right side.

Keywords - Shoulder; Brachial Plexus; Measures; Cadaver

\section{INTRODUCTION}

The axillary nerve originates from the fibers of the fifth and sixth cervical roots, which form the posterior fascicle of the brachial plexus. Its proximal portion is located laterally to the radial nerve, posteriorly to the axillary artery and anteriorly to the subscapular muscle. It emerges through the quadrangular space formed medially and laterally by the brachial triceps muscle, superiorly by the teres minor muscle and inferiorly by the teres major muscle, accompanied by the posterior humeral circumflex artery. It comes into contact with the inferior joint capsule of the shoulder and follows a posterior path to the surgical neck of the humerus, where it divides into two muscle branches (anterior and posterior) ${ }^{(1)}$. The anterior branch circles the surgical neck of the humerus anteriorly, beside the fibers of the deltoid muscle, innervating its clavicular and acromial portions. The posterior branch innervates the spinal portion of the deltoid muscle and the teres minor muscle, and is also responsible for sensory innervation of the superolateral part of the arm, through a terminal sensory $\operatorname{branch}^{(2)}$.

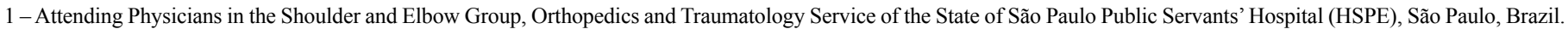

2 - Head of the Shoulder and Elbow Group, Orthopedics and Traumatology Service of the State of São Paulo Public Servants' Hospital (HSPE), São Paulo, Brazil.

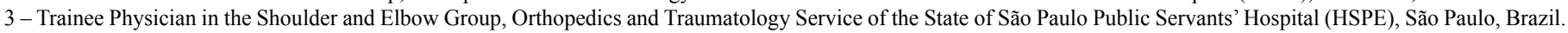

Work performed in the Orthopedics and Traumatology Service of the State of São Paulo Public Servants' Hospital (HSPE).

Correspondence: Rua Francisco Leitão, 474, apto. 92 - Pinheiros - 05414-020 - São Paulo, SP. E-mail: actenorjr@hotmail.com
}

Work received for publication: March 01, 2009; accepted for publication: April 21, 2009. 
According to Steimann et al, the anterior branch of the axillary nerve is located between 3 and 7 $\mathrm{cm}$ inferiorly to the lateral margin of the acromion ${ }^{(3)}$. Bono et $\mathrm{al}^{(4)}$ measured the distance between the most cranial point of the head of the humerus and the point where the axillary nerve divides into its anterior and posterior branches and found that this distance was $6.01 \pm 0.7 \mathrm{~cm}$. According to Burkhead et $\mathrm{al}^{(2)}$, the axillary nerve is located $5 \mathrm{~cm}$ from the lateral margin of the acromion.

Certain procedures may cause damage to the axillary nerve, and these include: proximal intramedullary locking nails for the humerus; fixation with percutaneous wires and screws; fixation with plates; arthroscopic portals; intramuscular injections; and even poor positioning of the spacers during surgical approaches to the proximal humerus ${ }^{(5,6)}$.

\section{The aims of the present study were:}

1) To establish a "safety zone" for the axillary nerve, by measuring its distance from the acromion and from the deltoid-pectoral access route;

2) To investigate whether there is any difference in comparative measurements between the right and left sides.

\section{MATERIAL AND METHODS}

Material - Between March 2004 and August 2005, 30 shoulders without previous scars from 20 fresh adult cadavers were dissected at the São Paulo Autopsy Service, at the University of São Paulo, with approval for the work from the Research Ethics Committee. Fifteen cadavers were male and five were female. Their weights ranged from 48 to $80 \mathrm{~kg}$, with a mean of $63.05 \mathrm{~kg}$, and their heights ranged from 1.60 to $1.90 \mathrm{~m}$, with a mean of $1.74 \mathrm{~m}$. Their ages ranged from 44 to 61 years, with a mean of 53 years (Tables 1 and 2).

Method - The cadavers were positioned in dorsolateral decubitus, with the shoulder in neutral rotation, the elbow flexed at $90^{\circ}$ and the forearm in mid-range pronosupination.

A horizontal access was used, parallel to the lateral margin of the acromion. The skin and subcutaneous tissue were pulled back and the deltoid muscle was exposed (Figure 1). The deltoid muscle was totally deinserted from the lateral margin of the acromion and the clavicle, and was pulled back laterally Figure 2). The axillary nerve and its branches were dissected from their emergence through the quadrangular space to the point at which its fibers penetrate the belly of the deltoid muscle (Figure 2).

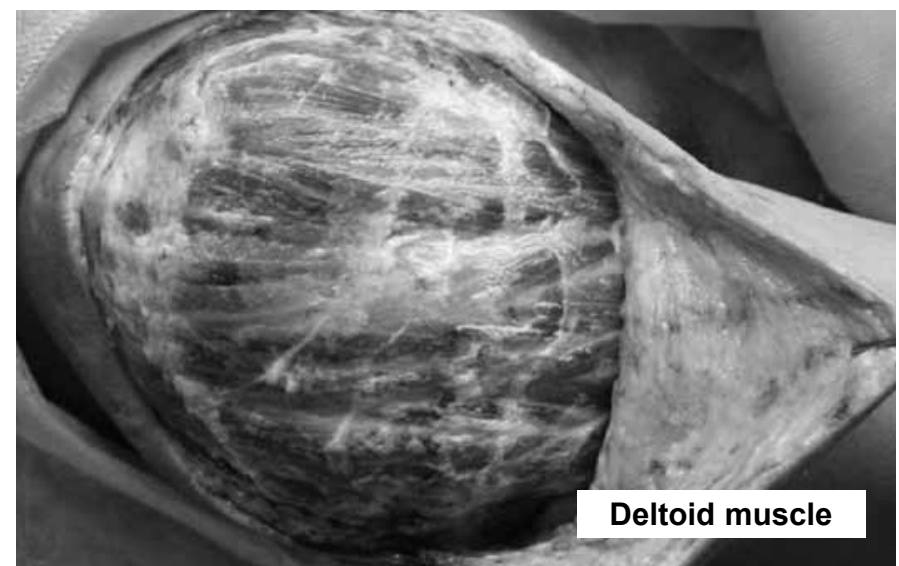

Figure 1 - Horizontal incision, parallel to the later margin of the acromion.

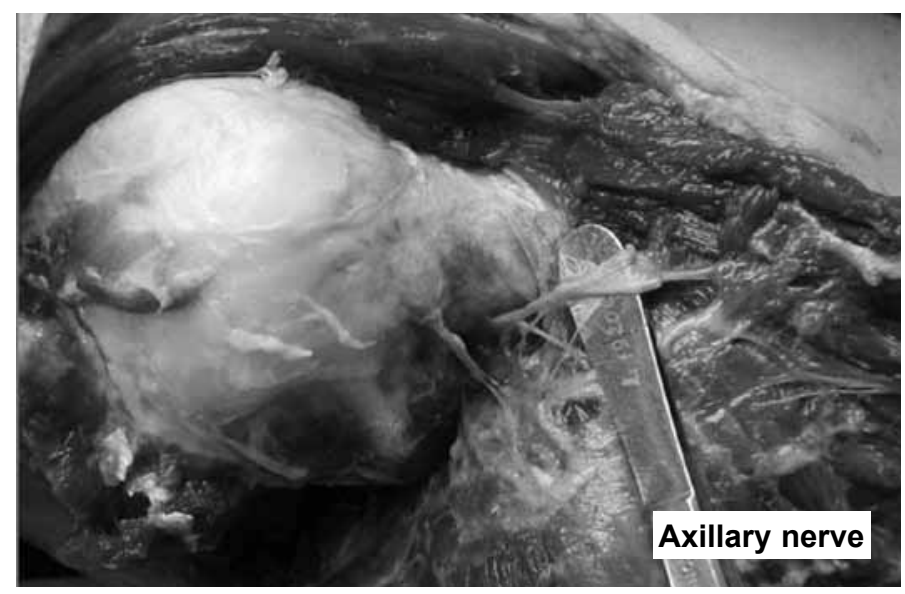

Figure 2 - Deltoid muscle deinserted from the acromion and clavicle, and pulled back laterally; axillary nerve dissected starting from its emergence through the quadrangular space.

\section{The following points were marked out using $12 \mathrm{x}$ $7 \mathrm{~mm}$ needles:}

1) On the axillary nerve:

$\mathrm{A}$ - at the humerus, $2 \mathrm{~cm}$ laterally to its emergence through the quadrangular space, using a $\operatorname{Codman}^{\circledR}$ pen (Figure 3).

$\mathrm{B}$ - at the belly of the deltoid muscle, in the most proximal portion of its anterior branch in relation to the acromion (Figure 4).

2) On the lateral margin of the acromion, at its anterior extremity $(\mathrm{C})$ and posterior extremity (D), and at the midpoint between points $\mathrm{C}$ and $\mathrm{D}(\mathrm{E})$ (Figure 5). 
Table 1 - Data and results obtained.

\begin{tabular}{|c|c|c|c|c|c|c|c|c|c|c|c|}
\hline Cadaver & Sex & $\begin{array}{c}\text { Age } \\
\text { (years) }\end{array}$ & Side & $\begin{array}{c}\text { Weight } \\
\text { (kg) }\end{array}$ & $\begin{array}{l}\text { Height } \\
(\mathrm{m})\end{array}$ & $\begin{array}{c}\text { Width of } \\
\text { acromion }(\mathrm{cm})\end{array}$ & $\begin{array}{l}\text { Distance } \\
\text { A-C (cm) }\end{array}$ & $\begin{array}{l}\text { Distance } \\
\text { A-D (cm) }\end{array}$ & $\begin{array}{l}\text { Distance } \\
\text { A-E (cm) }\end{array}$ & $\begin{array}{l}\text { Distance } \\
\text { B-C (cm) }\end{array}$ & $\begin{array}{l}\text { Distance } \\
\text { B-F (cm) }\end{array}$ \\
\hline 1 & $\mathrm{~m}$ & 57 & $\mathrm{R}$ & 68 & 1.75 & 4.09 & 7.14 & 6.72 & 7.23 & 5.45 & 3.95 \\
\hline 2 & $\mathrm{~m}$ & 46 & L & 50 & 1.74 & 5.77 & 8.32 & 8.12 & 8.48 & 5.03 & 3.25 \\
\hline 3 & $\mathrm{~m}$ & 52 & L & 58 & 1.70 & 4.65 & 6.71 & 6.45 & 6.93 & 5.13 & 3.84 \\
\hline 4 & $\mathrm{~m}$ & 44 & $\mathrm{R}$ & 60 & 1.60 & 4.63 & 7.61 & 7.43 & 7.02 & 5.22 & 3.97 \\
\hline 5 & $f$ & 48 & $\mathrm{R}$ & 48 & 1.70 & 4.42 & 7.68 & 7.20 & 7.64 & 5.05 & 3.36 \\
\hline 6 & $f$ & 56 & $\mathrm{R}$ & 60 & 1.60 & 5.24 & 8.78 & 6.32 & 6.54 & 5.52 & 4.22 \\
\hline 7 & $\mathrm{~m}$ & 59 & $\mathrm{R}$ & 80 & 1.90 & 5.70 & 7.11 & 7.51 & 7.74 & 5.32 & 4.35 \\
\hline 8 & $\mathrm{~m}$ & 54 & $\mathrm{R}$ & 75 & 1.75 & 6.07 & 8.13 & 6.81 & 6.72 & 5.52 & 4.12 \\
\hline 9 & $\mathrm{~m}$ & 57 & $\mathrm{R}$ & 68 & 1.80 & 4.47 & 8.28 & 6.21 & 6.66 & 5.15 & 3.29 \\
\hline 10 & $\mathrm{~m}$ & 61 & $\mathrm{R}$ & 75 & 1.80 & 4.53 & 8.12 & 7.73 & 7.03 & 5.49 & 4.30 \\
\hline \multirow[t]{2}{*}{11} & $f$ & 56 & $\mathrm{R}$ & 55 & 1.65 & 4.14 & 6.41 & 6.21 & 6.13 & 5.53 & 3.70 \\
\hline & & & L & & & 4.22 & 6.38 & 6.11 & 6.16 & 5.32 & 4.01 \\
\hline \multirow[t]{2}{*}{12} & $\mathrm{~m}$ & 47 & $\mathrm{R}$ & 60 & 1.73 & 4.23 & 6.31 & 5.94 & 6.32 & 5.60 & 3.50 \\
\hline & & & L & & & 4.23 & 6.24 & 6.16 & 6.22 & 5.21 & 4.10 \\
\hline \multirow[t]{2}{*}{13} & $\mathrm{~m}$ & 50 & $\mathrm{R}$ & 60 & 1.80 & 4.20 & 6.11 & 6.91 & 6.20 & 6.02 & 3.91 \\
\hline & & & L & & & 4.23 & 6.20 & 6.88 & 6.10 & 6.02 & 4.10 \\
\hline \multirow[t]{2}{*}{14} & $\mathrm{~m}$ & 46 & $\mathrm{R}$ & 50 & 1.82 & 4.52 & 6.83 & 5.81 & 6.52 & 6.03 & 4.61 \\
\hline & & & L & & & 4.32 & 6.61 & 5.21 & 6.21 & 5.21 & 5.11 \\
\hline \multirow[t]{2}{*}{15} & $f$ & 45 & $\mathrm{R}$ & 60 & 1.75 & 4.42 & 6.31 & 6.03 & 6.21 & 5.74 & 4.44 \\
\hline & & & L & & & 4.51 & 6.11 & 5.82 & 6.01 & 5.61 & 4.27 \\
\hline \multirow[t]{2}{*}{16} & $\mathrm{~m}$ & 59 & $\mathrm{R}$ & 74 & 1.72 & 3.95 & 5.14 & 5.04 & 5.03 & 5.41 & 5.62 \\
\hline & & & L & & & 3.55 & 5.62 & 5.06 & 4.97 & 5.12 & 5.72 \\
\hline \multirow[t]{2}{*}{17} & $\mathrm{~m}$ & 54 & $\mathrm{R}$ & 68 & 1.81 & 4.20 & 6.11 & 6.91 & 6.20 & 6.02 & 3.91 \\
\hline & & & $\mathrm{L}$ & & & 4.23 & 6.20 & 6.88 & 6.10 & 5.95 & 4.10 \\
\hline \multirow[t]{2}{*}{18} & $\mathrm{~m}$ & 58 & $\mathrm{R}$ & 65 & 1.70 & 4.43 & 6.26 & 6.71 & 6.25 & 6.15 & 4.01 \\
\hline & & & $\mathrm{L}$ & & & 4.24 & 6.13 & 6.61 & 6.15 & 6.04 & 3.91 \\
\hline \multirow[t]{2}{*}{19} & $\mathrm{~m}$ & 52 & $\mathrm{R}$ & 72 & 1.75 & 4.48 & 6.37 & 6.96 & 6.37 & 6.27 & 4.04 \\
\hline & & & L & & & 4.51 & 6.56 & 6.80 & 6.47 & 6.47 & 4.24 \\
\hline \multirow[t]{2}{*}{20} & $f$ & 60 & $\mathrm{R}$ & 55 & 1.65 & 4.15 & 6.34 & 6.26 & 6.13 & 6.04 & 4.13 \\
\hline & & & L & & & 4.07 & 6.28 & 6.13 & 6.03 & 5.94 & 4.02 \\
\hline
\end{tabular}

Note: for the last ten cadavers, measurements were made on both the right and the left side.

Table 2 - Biometrics on the cadavers.

\begin{tabular}{l|c|c|c|c}
\hline & & $\begin{array}{c}\text { Weight } \\
(\mathbf{k g})\end{array}$ & $\begin{array}{c}\text { Height } \\
(\mathbf{m})\end{array}$ & $\begin{array}{c}\mathbf{B M I} \\
\mathbf{( k g / \mathbf { m } ^ { 2 }} \mathbf{)}\end{array}$ \\
\hline & Mean & 63.05 & 1.74 & 20.92 \\
\hline & Standard deviation & 9.23 & 0.08 & 2.73 \\
\hline & Median & 60.00 & 1.75 & 20.87 \\
\hline & Minimum & 48.00 & 1.60 & 15.09 \\
\hline${ }^{*} 95 \% \mathrm{Cl}$ & Maximum & 80.00 & 1.90 & 25.01 \\
\hline & & & & \\
\hline & LL & 59.00 & 1.70 & 19.73 \\
\hline
\end{tabular}

*95\% CI: $95 \%$ confidence interval for the study population; LL: lower limit of the confidence interval; UL: upper limit of the confidence interval.
3) On the deltopectoral groove:

$\mathrm{F}$ - at the point most proximal to point B (Figure 4). Using a Mistainless ${ }^{\circledR}$ digital caliper gauge, the following distances were measured:
A - C (Figure 6)
$\mathrm{A}-\mathrm{D}$ (Figure 6).
$A-E$ (Figure 6).
$\mathrm{B}-\mathrm{C}$ (Figure 6).
$\mathrm{B}-\mathrm{F}$ (Figure 7). 


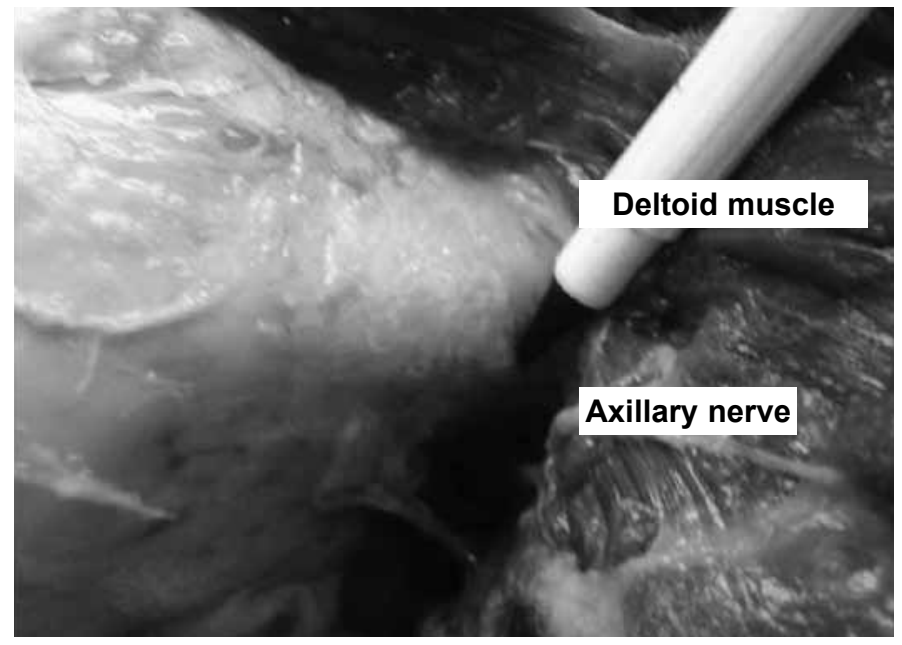

Figure 3 - Mark-up of the axillary nerve on the humerus, $2 \mathrm{~cm}$ laterally to its emergence through the quadrangular space.

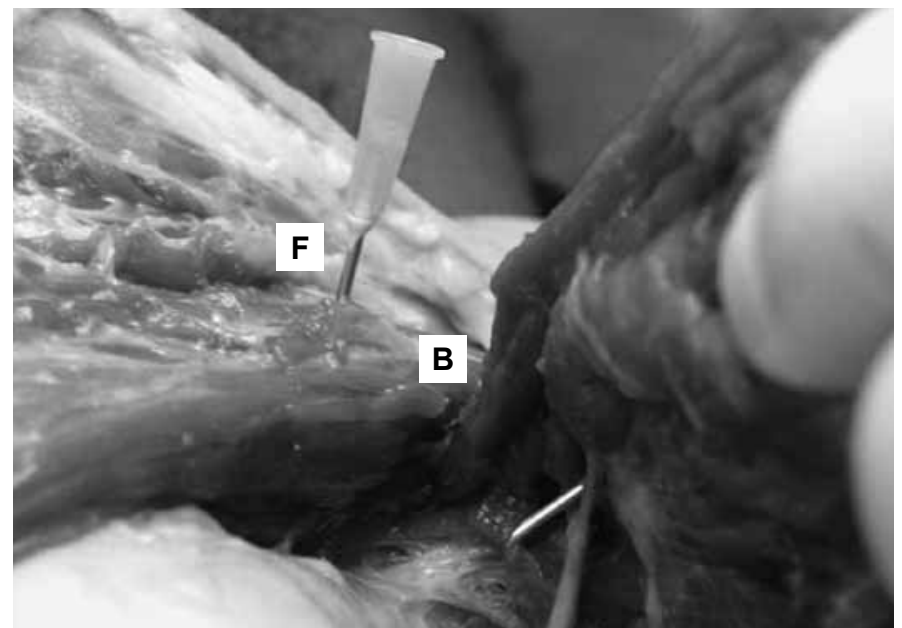

Figure 4 - Mark-up of the anterior branch of the axillary nerve, at the end that is most proximal to the acromion (B), and on the deltopectoral groove $(\mathrm{F})$ at the point that is most proximal to point $\mathrm{B}$.

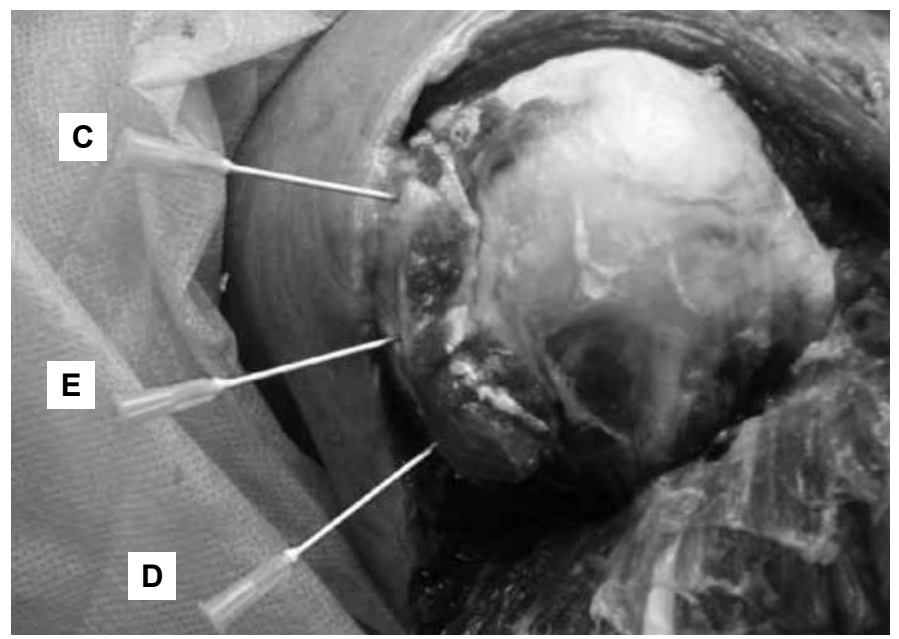

Figure 5 - Mark-up of the lateral margin of the acromion: anterior extremity (C) and posterior extremity (D), and the midpoint between the extremities $(E)$.

Rev Bras Ortop. 2011:46(3):309-14

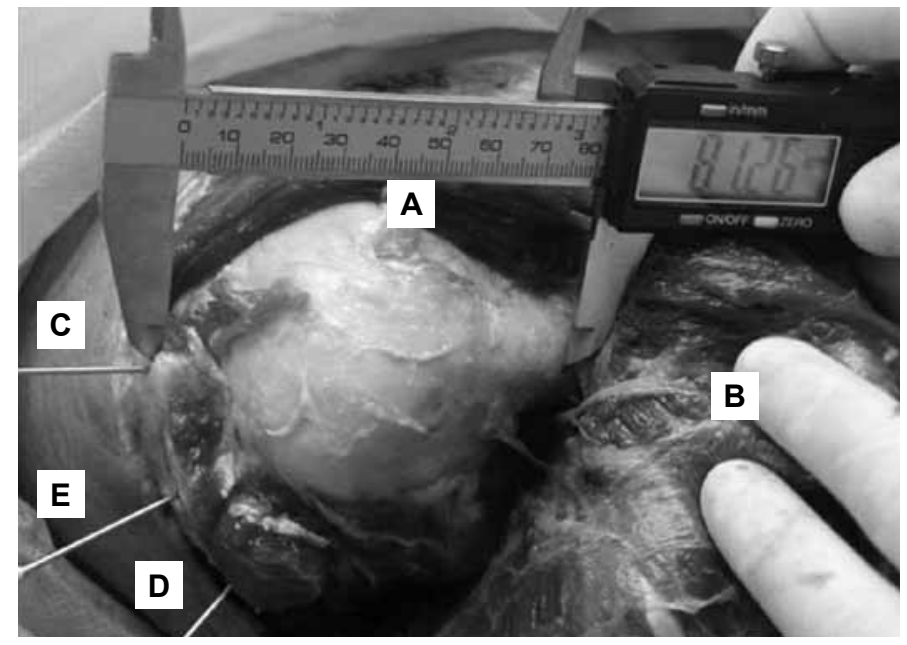

Figure 6 - Measurement of the distances A-C, A-D, A-E and $\mathrm{B}-\mathrm{C}$, using a digital caliper gauge.

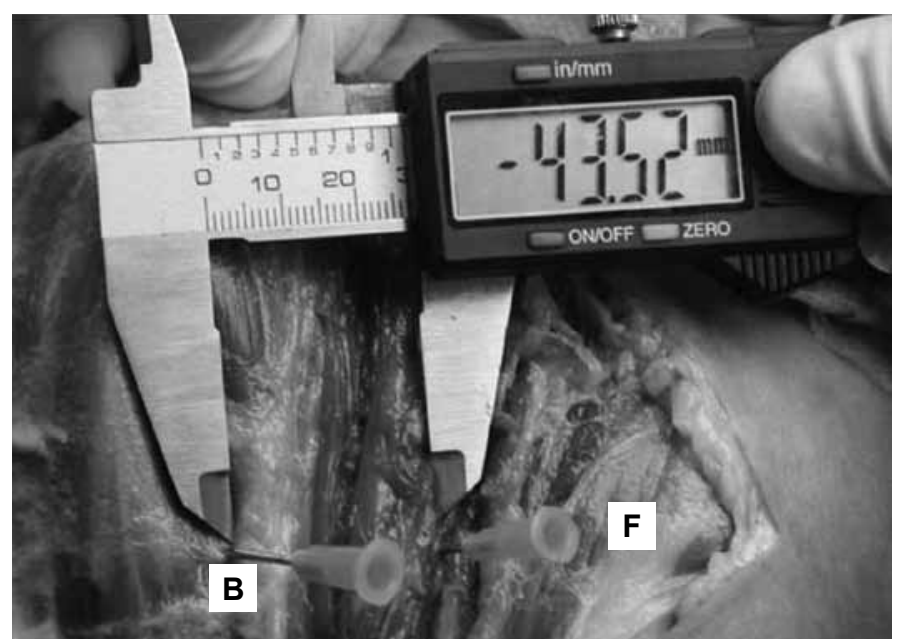

Figure 7 - Measurement of the distance B-F, using a digital caliper gauge.

\section{RESULTS}

The data and the results obtained are in Table 1 and the statistical analysis is in Tables 2, 3 and 4.

Anterior branch - The distance between the acromion and the anterior branch of the axillary nerve ranged from 5.03 to $6.47 \mathrm{~cm}$, with a mean of 5.23 $\mathrm{cm}$. The standard deviation was $4.09 \mathrm{~cm}$. Comparative analysis between the right and left sides showed that the difference between the means of the measurements was $0.19 \mathrm{~cm}(\mathrm{p}=0.027)$.

Posterior branch - The distance between the anterior extremity of the acromion and the posterior branch of the axillary nerve ranged from 5.14 to 8.78 $\mathrm{cm}$, with a mean of $6.5 \mathrm{~cm}$. The standard deviation was $8.79 \mathrm{~cm}$. Comparative analysis between the right and left sides showed that the difference between 
the means of the measurements was $0.14 \mathrm{~cm}(\mathrm{p}=$ 0.922). The distance between the posterior extremity of the acromion and the posterior branch of the axillary nerve ranged from 5.04 to $8.12 \mathrm{~cm}$, with a mean of $6.50 \mathrm{~cm}$. The standard deviation was 7.34 $\mathrm{cm}$. Comparative analysis between the right and left sides showed that the difference between the means of the measurements was $0.65 \mathrm{~cm}(\mathrm{p}=0.084)$. The distance between the midpoint of the anterior and posterior extremities of the acromion and the posterior branch of the axillary nerve ranged from 4.97 to 8.48 $\mathrm{cm}$, with a mean of $6.46 \mathrm{~cm}$. The standard deviation was $7.05 \mathrm{~cm}$. Comparative analysis between the right and left sides showed that the difference between the means of the measurements was $0.1 \mathrm{~cm}(\mathrm{p}=0.014)$.

Deltopectoral space - The distance between the anterior branch of the axillary nerve and the deltopectoral space ranged from 3.25 to $5.72 \mathrm{~cm}$, with a mean of $4.14 \mathrm{~cm}$. The standard deviation was 5.60 $\mathrm{cm}$. Comparative analysis between the right and left sides showed that the difference between the means of the measurements was $0.56 \mathrm{~cm}(\mathrm{p}<0.065)$.

Table 3 - Statistical analysis on the results obtained.

\begin{tabular}{|c|c|c|c|c|c|c|c|}
\hline & & $\begin{array}{c}\text { Width of } \\
\text { acromion }(\mathrm{cm})\end{array}$ & $\begin{array}{c}\text { Distance A-C } \\
(\mathrm{cm})\end{array}$ & $\begin{array}{c}\text { Distance A-D } \\
(\mathbf{c m})\end{array}$ & Distance A-E (cm) & Distance B-C (cm) & $\begin{array}{c}\text { Distance B-F } \\
(\mathbf{c m})\end{array}$ \\
\hline & Mean & 4.48 & 6.50 & 6.50 & 6.46 & 5.23 & 4.14 \\
\hline & Standard deviation & 5.44 & 8.79 & 7.34 & 7.05 & 4.09 & 5.60 \\
\hline & Median & 4.37 & 6.37 & 6.53 & 6.23 & 5.52 & 4.0 .7 \\
\hline & Minimum & 3.55 & 5.14 & 5.04 & 4.97 & 5.03 & 3.25 \\
\hline & Maximum & 6.07 & 8.78 & 8.12 & 8.48 & 6.47 & 5.72 \\
\hline \multirow[t]{2}{*}{ *95\% Cl } & LL & 4.28 & 6.43 & 6.24 & 6.21 & 5.47 & 3.94 \\
\hline & UL & 4.67 & 7.06 & 6.76 & 6.71 & 5.76 & 4.34 \\
\hline
\end{tabular}

*95\% CI: $95 \%$ confidence interval for the study population; LL: lower limit of the confidence interval; UL: upper limit of the confidence interval.

Table 4 - Comparative analysis between the right and left sides (last ten cadavers).

\begin{tabular}{|c|c|c|c|c|c|c|c|c|c|}
\hline & & & & & & & \multicolumn{2}{|c|}{$95 \% \mathrm{Cl}$} & \multirow[b]{2}{*}{$\mathbf{p}^{\star}$} \\
\hline Variable & Side & Mean & SD & Median & Minimum & Maximum & LL & UL & \\
\hline \multirow{2}{*}{$\begin{array}{c}\text { Width of } \\
\text { acromion }(\mathrm{cm})\end{array}$} & Right & 4.27 & 1.82 & 4.22 & 3.95 & 4.52 & 4.60 & 4.38 & 0.625 \\
\hline & Left & 4.21 & 2.68 & 4.23 & 3.55 & 4.51 & 4.04 & 4.38 & \\
\hline \multirow[t]{2}{*}{ Distance A-C $(\mathrm{cm})$} & Right & 6.22 & 4.29 & 6.31 & 5.14 & 6.83 & 5.95 & 6.48 & 0.922 \\
\hline & Left & 6.36 & 2.74 & 6.22 & 5.62 & 6.61 & 6.06 & 6.06 & \\
\hline \multirow[t]{2}{*}{ Distance A-D (cm) } & Right & 6.82 & 6.12 & 6.24 & 5.04 & 6.96 & 5.90 & 6.61 & 0.084 \\
\hline & Left & 6.17 & 6.55 & 6.15 & 5.06 & 6.88 & 5.76 & 6.76 & \\
\hline \multirow[t]{2}{*}{ Distance A-E (cm) } & Right & 6.14 & 4.06 & 6.21 & 5.03 & 6.52 & 5.89 & 6.39 & 0.014 \\
\hline & Left & 6.04 & 3.98 & 6.12 & 4.97 & 6.47 & 5.79 & 6.29 & \\
\hline \multirow[t]{2}{*}{ Distance B-C $(\mathrm{cm})$} & Right & 5.88 & 2.90 & 6.02 & 5.41 & 6.27 & 5.70 & 6.06 & 0.027 \\
\hline & Left & 5.69 & 4.60 & 5.77 & 5.12 & 6.47 & 5.40 & 5.97 & \\
\hline \multirow[t]{2}{*}{ Distance B-F (cm) } & Right & 4.92 & 5.96 & 4.00 & 3.50 & 5.62 & 3.82 & 4.56 & 0.065 \\
\hline & Left & 4.36 & 5.84 & 4.10 & 3.91 & 5.72 & 4.00 & 4.72 & \\
\hline
\end{tabular}




\section{DISCUSSION}

Studying the path of the axillary nerve and establishing its location in relation to the anatomical parameters used here may help surgeons to avoid injuring the nerve during open surgical procedures. Such injuries could occur if the access route lies within the safety zone, or because of inadequate or prolonged positioning of spacers on the deltoid muscle.

In arthroscopy, the axillary nerve may also be injured, in positioning an accessory distal posterior arthroscopic portal, at the point where it comes out from the quadrangular space and turns anteriorly, approximately $5 \mathrm{~cm}$ distally to the acromion, through using heat-generating instruments on the lower capsule. This may also occur while removing lower humeral spurs.

According to Albritton et $\mathrm{al}^{(6)}$, the mean distance between the axillary nerve and proximal locking screw of the intramedullary nail used is $0.26 \mathrm{~cm}$, and nerve injuries may occur during the proximal locking, in treating fractures of the humerus. According to these authors, the risk of injury is greater for smaller humerus bones. For greater safety, they recommended that the deltoid muscle should be dissected and the lateral cortical bone of the humerus should be brought into direct view, with use of soft-tissue protection.

Meireles et $\mathrm{al}^{(5)}$ reported a case of axillary nerve injury while applying an injection to the deltoid muscle. In our study, the anterior branch of the axillary nerve was located at a distance of between $5.47 \mathrm{~cm}$ and $7.06 \mathrm{~cm}$ from the lateral margin of the acromion.
This is precisely the location recommended in the past for application of intramuscular injections, which makes this now-proscribed technique dangerous ${ }^{(5,7)}$.

We agree with Ferreira Filho et al ${ }^{(1)}$, who demonstrated that the axillary nerve can be injured in cases of lateral access through the deltoid muscle, in procedures that require greater surgical exposure. Surgeons need to know how far it is possible to expand the operative incision caudally without compromising the integrity of the axillary nerve ${ }^{(8)}$.

In orthopedic surgery, the deltopectoral access route is used for a variety of pathological conditions of the shoulder, such as osteosynthesis of fractures, arthroplasty and repairs to labral lesions ${ }^{(8)}$. The axillary nerve needs to be protected, thereby avoiding paralysis of the deltoid muscle and functional impairment of the shoulder ${ }^{(1,9-12)}$. Knowledge of its path and anatomical relationships is important in this respect $t^{(1,12-14)}$.

In a study carried out on 67 cadavers at the University of Crete, in Greece, Kontakis et al ${ }^{(15)}$ found three cases (two women) in which there was a difference of $1-2 \mathrm{~cm}$ in the position of the axillary nerve between the right and left sides.

\section{CONCLUSIONS}

The axillary nerve was located between 5.47 and $7.06 \mathrm{~cm}$ distally to the acromion and $3.94 \mathrm{~cm}$ laterally to the deltopectoral space. There was a statistically significant difference in comparing between the right and left sides, such that both distances were greater on the right side.

\section{REFERENCES}

1. Ferreira Filho AA, Suzuki JM, Ferreira M. O nervo axilar na abordagem cirúrgica do ombro. Rev Bras Ortop 1989; 24(5):176-8.

2. Burkhead W, Scheinberg R, Box G. Surgical anatomy of the axillary nerve. J Shoulder Elbow Surg. 1992;1(1):31-6.

3. Steinmann SP, Moran EA. Axillary nerve injury: diagnosis and treatment. J Am Acad Orthop Surg. 2001;9(5):328-35.

4. Bono M, Grossmam MG, Hochwald N, Tornetta P. Radial and axillary nerves: anatomic considerations for humeral fixation. Clin Orhtop Relat Res. 2000;(300):259-64.

5. Meirelles H, Motta Filho GR. Lesão do nervo axilar causada pela injeção intramuscular no deltóide: relato de caso. Rev Bras Ortop. 2004;39(10):615-9.

6. Albritton MJ, Barnes CJ, Karas SG. Relationship of the axillary nerve to the proximal screws of a flexible humeral nail system: an anatomic study. J Orthop Trauma. 2003;17(6):411-4

7. Pery AG, Potter PA. Clinical nursing skills and technique. St. Louis: Mosby; 1998. p. 631.

8. Rocha RP, Lenza MV, Lenza M, Mongon ML, Ribeiro FB, Braga EV, et al.

Rev Bras Ortop. 2011;46(3):309-14

Relações do nervo axilar com o músculo axilar: sua importância no acesso delto-peitoral. Rev Bras Ortop 2002;37(3):79-82.

9. Bryan WJ, Schauder R, Tullos HS. The axillary nerve and its relationship to commom sport medicine shoulder procedures. Am J Sports Med. 1986;14(2):113-6.

10. Flatow EL, Bigliani LU. Tips of the trade. Locating and protecting the axillary nerve in shoulder surgery: the tug test. Orthop Rev. 1992;21(4):503-5.

11. Loomer R, Graham B. Anatomy of axillary nerve and its relation to inferior caspsular shift. Clin Orthop Relat Res. 1989; (243):100-5.

12. Durval MJ, Parker AW, Drez D Jr, Hinton MA. The anterior humeral circumflex vessel and the axillary nerve: an anatomic study. Orthop Rev. 1993;22(9):1023-6.

13. Rowles DJ. McGrory JE. Percutaneous pinning of the proximal part of the humerus. An anatomic study. J Bone Joint Surg Am. 2001;83(11):1695-9.

14. Moran MC. Distal interlocking during intramedullary nailing of the humerus. Clin Orthop Relat Res. 1995;(317):215-8.

15. Kontakis, GM, Steriopoulos K, Damilakis J, Michalodimitrakis E. The position of the axillary nerve in the deltoid muscle: A cadaveric study. Acta Orthop. 1999;70(1):9-11. 